\title{
New possibilities of emergency communication and information in the protection phase of disaster management
}

\author{
TEKNŐS László ${ }^{1}$, ENDRŐDI István ${ }^{2}$
}

\begin{abstract}
Today, because of social, technological and climate changes, incidents and di-sasters have an increasing impact on life and property safety. For this reason, the importance and role of emergency information to the public is becoming more important and vital. Providing real-time information by the authorities, guidelines for the population and rules of conduct increase the individual's ability to survive. The increasingly developed information systems, designed to inform the public and raise the level of safety culture all seek to support the effectiveness of social protection capabilities. In this study, the authors attempt to analyze and evaluate the importance of emergency communication and (public) information in disaster management. They are researching new ways for communication options and methods that promote and support the survival conditions of the population in the protection phase.

Keywords: disaster management, emergency, social media, public awareness
\end{abstract}

\section{Introduction}

With the development of information and communication technologies, the opportunities for providing public information have widened. With social transformation, the demand for the widest possible access to public information and publicity is playing an increasingly im- portant role. Obtaining information by communities has now become simpler and quicker. While in the past, time and space played an important role in the transmission and reception of information, nowadays, these factors no longer cause problems, because the Internet, over- coming physical boundaries, has dismantled the framework of immobility. Social media has become one of the most relevant elements of this accelerated flow of information.

Due to the large number of users in Hungary, it is essential to consider adapting the possi- bilities and methods offered by social media in the protection mechanism in Hungary as well, especially in public emergency information. As the March snow situation and the flooding of the Danube in June 2013 also showed, there was a demand by the public that the professional bodies should apply these new info-communication technologies.

The timeliness of the topic is shown in the latter. Incidents in recent years, originating in nature or human activity, all show that society is vulnerable anywhere and at any time at

1 Doctorandus student, Military Technical Ph.D. School, Faculty of Military Science and Army Officer Training, National University of Public Service, Budapest, Hungary, teknos.laszlo@uni-nke.hu,

2 Head of Department for Disaster Management Operations, National University of Public Service, Budapest, Hungary, endrodi.istvan@uninke.hu 
a certain level. The effects of incidents involving strong psychic impact may be mitigated according to the preparedness and the presence of mind of the stakeholders; the number of life-endangering situations may be reduced. These goals can be achieved by raising public awareness and emergency communication.

\section{Introducing and Interpreting Current Emergency Communication}

The security situation in Hungary over the last 20 years has undergone/is undergoing con- stant changes. The Cold War approach has gradually developed into actions and response activities against the challenges caused by natural disasters. The range of risks and hazards threatening safety and security has grown and become more complex (problems caused by extreme weather, political and climate migration, international terrorism, drug trafficking, illegal arms trafficking, black market penetration, etc.). These challenges have fundamentally changed the protection system in Hungary, thus creating the conditions for effective action against contemporary threats.

The Fundamental Law stipulates, in several points, the safety and protection of its nation- als, the best reference of which is paragraph (2) of Section G), according to which "Hungary protects its citizens." Hungary provides for the protection and defense of its citizens as a state task. [1] One of the important elements of this obligation is the uniform disaster management organization, established in 2012 (hereinafter Disaster Management), whose integrated scope of tasks consists of industrial safety, civil protection and fire safety. The new legal regulation and the Government's policy have determined to strengthen prevention and authoritative work, to increase response capability and to protect the life and integrity of the population and to protect its property. The law in Hungary prescribes the implementation of the suc- cessful management of disasters or emergencies, including the strengthening of emergency communication.

On the road to an Internet-based society, one can see abroad (e.g. in the case of Hurricane Sandy) that emergency calls by the population, avoiding the overloaded and congested dis- tress call systems were made on the social media sites of the authorities. Non-governmental self-protection efforts have founded the government-level utilization of social media sites in emergency public communication. In Hungary, the snow situation in March and the flood of the Danube in June 2013 were the two incidents that launched the involvement of social me- dia in raising public awareness and informing the organizations participating in the protection efforts. On the Facebook page "Hóhelyzet 2013 március" (Snow situation March 2013), the following initial script was uploaded: "For those stuck in the snow and are in trouble and for those who would like to help or share information. Let's help if we can." [2] This page was created on 14 March 2013. The last posts were made on 17 March, but there are still 159 likes this page enjoys (as of 03 February 2014). Mainly the homepage information of the National Police Headquarters, the animated wind maps of "Idökép", the images taken by the Hungar- ian Defense Forces and the Hungarian News Agency (Magyar Távirati Iroda — MTI) were shared in the duration of three days. Watching the organization of non-governmental organi-zations (NGOs), a lesson can be drawn that the population uses a new kind of space to obtain information. Social media is another option for a broad range of emergency information to the public. The snow situation was the first extraordinary situation, where the population 
used Facebook to receive help and inform each other. Also in connection with the June 2013 flooding, it can be observed that non-governmental entities used Facebook to organize them- selves. The page "Árvíz 2013 Összefogás" (Join Forces, Flood 2013) was created on 02 June. There were 42512 likes by 17 September 2013. [3] The last post was made on 18 June, which means that the originator of the page did not run it any longer. With such a great number of likes, it is unacceptable. It would be a waste to ignore this crowd, so the next reasonable step for the admin would be to forward them to the information sites of National Directorate Gen- eral for Disaster Management, Ministry of the Interior (NDGDM). However, it can be seen that in case of an extraordinary incident the number of persons demanding information in- creases a huge amount. The basis of involving social media in emergency communication and information is triggered by the increasing number of incidents and emergencies in Hungary, and is created by the NGOs of the social media. However, self-organization has its dangers as well, since the large amount of data is not controlled by the authorities in most of the cases, thus the possibility of disinformation is higher. On the official Facebook portal of Disaster Management the information is verified, the communication is authentic. The administrators monitor the responses of the population in the prevention, response and recovery phases.

\subsection{The significance of emergency communication in emergencies}

An extraordinary event always gets more attention from the public. Generally speaking, at suddenly occurring incidents affecting larger masses the public frantically search for chan- nels providing information. The more a greater incident escalates in space and time, the more people will come to a close-to-panic situation through their self-organizations, then lose their self-control, to a life-threatening condition or situation. The people in need re- quire quick and authentic information, related to "survival". It is important that the person communicating information should only concentrate, without revealing their emotions, on emergency tasks, and should accordingly mediate it to the needy.

The response by citizens to an incident depends on the style and comprehensibility of the channel providing the information (media, narrator, and courier). Utmost importance is at- tached to the onsite reporters in the incident sites, since public media, commercial television channels and radios transmit news and information to a large number of consumers. General- ly speaking, it can be witnessed that the reporters do not appropriately use terms related to di- saster management; they explain their meaning in a different way. In an emergency or after an incident quick, precise and essential emergency communication and public information have priority. Media people perform their coverage many times in areas that are prone to accidents. Therefore, it is important that they receive labor safety and accident prevention training.

On 29 January 2014, the National Directorate General for Disaster Management held a one-day training for journalists who intend to become emergency correspondents. The goal of this training is that the media informing large masses have adequate quality and quantity of disaster management knowledge. They received information on the vulnerability of Hungary, the classification of Hungarian settlements, recognizing threat factors, the significance of crisis communication, emergency communication, means of alert, the basics of disaster man- agement, hydrological and meteorological forecasting, the basic rules of moving in incident sites, the use of protective equipment, labor safety regulations, rules of conduct in incident sites, flow of information, emergency notification services, etc. [4] 
Citizens have the right to learn of incident site information. The media strongly influences public opinion by transferring values and the contents of communication. Authorities and the media are responsible towards the population. [5: 92] In case of the occurrence of an extraor- dinary event numerous disinformation effects may come to the fore, which must be managed (it would be more purposeful to avoid them, but it is very difficult and complicated in the information society of today). The quality of information is very important. The media is to provide information to the target audience, the aim of the authorities is to achieve safety of life and property through emergency communication and information, to reduce unnecessary conflicts, to prevent the development of panic, etc. The two should converge towards each other, or more precisely, the authorities (mainly professional emergency responders) should prepare the media representatives for emergency correspondence so that the information is more accurate, professional and reliable. Thus, the population will be provided at the ade- quate time with information of adequate quality, increasing their chances of survival.

As far as the participants in communication, the most authentic sources are the authori- ties, whose data and information are transmitted to the end users, the population by the me- dia. Through traditional channels (television, radio, written press, etc.), the media have the most opportunities to provide the masses with information. The use of social media and the Internet by the authorities made it possible for the responders to quickly reach the population in a factual and reliable way.

Generally speaking, the damages caused by the devastating effects of disasters and inci- dents can be mitigated by the preparation of the population and emergency communication. In North America, for example, the financial losses and human tragedies caused by Hurricane Katrina in 2005, on the one hand, can be attributed to the unprepared rescue forces, on the other hand to the unawareness of the public. [6: 5] However, in the case of Hurricane Sandy in 2012, fewer losses occurred in human lives. The reason for this (although it was larger in size than Hurricane Katrina) is to be found in the preventive and operational response mea- sures of governmental bodies and agencies involved in protection. An important factor is that the social networking sites, mobile applications were also used for effective protection. It was proven that massive distress calls during emergencies could not be accepted and processed by the aid reception system of the body in charge. The population, self-organizing, looked for options (such as social media, interactive maps, mobile apps, etc.). At the time of Hurricane Katrina, public emergency information was poorly organized, but during Hurricane Irene in

2011, public information was used properly in time. In the case of Hurricane Sandy, public information was already on an adequate level, emergency communication worked well. So- cial media was also involved; Hurricane Sandy received an independent page on Facebook, which had nearly two hundred thousand likes (quality indicator). [7: 290]

Emergency communication and information, besides traditional channels, was imple- mented through the latter. One can make the conclusion that the new opportunities (mo- bile applications, social networking, and interactive maps) should be used by the authorities during emergency communication and information.

One of the important, widely used possibilities of emergency communication is bilateral communication. Certain elements of social media may make bilateral communication more successful and efficient, which may create the conditions for the population staying alive by providing appropriate information to an individual at a suitable time (for example, appropri- ate rules of conduct, emergency knowledge, etc.) so they can avoid tragedy or escape from 
life endangering situations, quickly and without losses. Interactive communication systems belong to the best means of emergency information in the $21^{\text {st }}$ century, which assist disaster management through a rapid provision of information and the reception of verified infor- mation from the population. Based on the information from the population, a virtual picture can be compiled of an incident, which may be transmitted to the onsite commander or the person in charge of controlling the response activities. The interactivity of the communica- tions system lies in the fact that the receiving party obtains and collects information from the sender, which is processed by the recipient and it makes decisions based on the knowledge and expertise available, which is fed back to the sender in a utilizable format, orally or in writing. The sender may respond to it once again, thus launching bilateral communication. Interactivity always presumes actions from the user.

\section{Principlesand Methods of Public Information in an Emergency}

Population protection is primarily a basic civil protection task, but it includes all princi- ples, strategies, complex protection activities, procedures guaranteeing safety and security, in space and time, which are able to support and ensure the safeguarding of the population and property against a natural and/or man-made hazard or challenge.

Population protection is a partly military (air defense, armed defense, border guarding), and partly a law enforcement (public security, civil protection, etc.) task. In Hungary, the bodies and entities participating in population protection are in close connection with each other, however, population protection is mainly a civil protection "monopoly", with the pro- vision that civil protection may not support armed actions. Civil protection supports preventive protection measures, the mitigation of the devastating effects of natural or man-made disasters, and following such incidents or disasters, it assists in the creation of the basic life- support conditions for the population, and to safeguard human lives and property.

Experience shows that inhabitants (mainly those in trouble and need), following or during an incident or disaster, are not continuously informed on situations, or they receive false information or useless advice from numerous sources. It must be managed. By making in- formation from a controlled source available to the population negative information can be corrected. By this, the detrimental effect of disinformation may be reduced. With the help of the emergency information having a population protection aspect, provided by social media pages opening towards the population, and other applications, homepages, the sympathy of the population may be guaranteed. Thus, the population will be aware of their susceptibility and possibilities for help in an emergency and the people will know proper conduct.

A dangerous establishment can hold risk for the public therefore it has the right to know the possible dangerous effects, the methods of response to them, the behaviour to be followed after a major industrial accident involving dangerous substances. Depending on the substanc- es and technologies used, the risks may range from health risks, explosion, contamination, etc. The operator of the dangerous establishment is obliged to give correct information about the establishment, hazard sources to be found there and planned measures to prevent and respond to major accidents. The Hungarian regulation on major accident prevention defines the requirements, methods and means of guaranteeing publicity. [8] The means of the in- formation used for the purposes of prevention of major accidents are information materials, open hearings and public information that are provided during the emergency situation. [9] 


\subsection{A short introduction of emergency information}

To understand public information, the Act on Disaster Management will be of help. In Act CXXVIII of 2011 [10], public information is part of the tasks of civil protection in relation to disaster management described in Section 52.

The contents of public information should have the following components:

- briefing on the current situation;

- defining and identifying the population and area affected;

- information on the rules to be immediately introduced (rules of proper conduct);

- procedure of providing protective equipment;

- procedure of evacuation, rescue and reception;

- designating assembly points, briefing on the content of the emergency package;

- possibilities of sheltering in a building;

- (bomb) shelter protection (method of access, addresses);

- determining the method and place of individual protection;

- medical rules and support;

- major items of self- and mutual assistance;

- reading public administration decisions (ordering public labor, traffic restrictions, etc.).

Based on paragraph (1) of Section 37 of Government Decree 234/2011. (XI. 10.) [11] on the implementation of Act CXXVIII of 2011 on Disaster Management and on the Amend- ment of Certain Acts in Relation [10]: the contents of emergency information shall include:

- the danger of disaster, the incident occurred, protection, proper rules of conduct, pop- ulation protection measures, restrictions ordered and further information possibilities;

- in the recovery phase, the creation of basic accommodation conditions, the possibili- ties of mitigation on a separate decision and recovery itself.

If law does not provide otherwise, the responsible person for the emergency information of the population is:

- the minister responsible for the protection against disasters;

- the head of the central public administration organ;

- the head of the central and territorial professional disaster management organ;

- the chair of the county and local protection committee;

- the mayor of Budapest, mayor;

- the head of the business unit.

\subsubsection{Joint rules of emergency information}

Paragraph (1) of Section 34 of Government Decree 234/2011. (XI. 10.) [11] on the imple- mentation of Act CXXVIII of 2011 on Disaster Management and on the Amendment of Cer- tain Acts in Relation [10] contains the rules of emergency information, according to which the methods of alarming the population and emergency information are as follows:

- Primarily by public service announcements, according to the provisions of the Act on Media Services and Mass Communication. Paragraph (6) of Section 32 of Act CLXXXV of 2010 on Media Services and Mass Communication [12] stipulates, if it is justified based on the decision of the disaster management entity, and the decision has been communicated to the media service provider in time, the public media service 
provider is obliged to announce it by breaking its program. The obligation described in the latter paragraph is born by the media service provider of the social media service provider;

- Through the means of the public alarm system, whose definition is stipulated by the Act on Disaster Management "the entirety of public alarm, warning, storm warning systems and devices and equipment closely related to their functioning operated by the central organ of the professional disaster management organ and the territorial organs of the professional disaster management organs. " [10];

- In case of the availability of technical conditions, through electronic telecommuni- cations means. Elements of landline telecommunication: T-COM Rt., INVITEL Rt., etc.; fixed line broadcasting: cable television — local service provider; wireless tele- communication: T-Mobile, Telenor, Vodafone; wireless broadcasting: television lo- cal service provider, individual antennas can serve as signal receivers;

- In a way that is customary locally (loudspeakers, courier, posters);

- Through other means locally available for alarming and announcing emergency infor- mation, including loudspeakers capable of transmitting live speech belonging to law enforcement and private entities, and hand-held loudspeakers.

Naturally, in order to achieve efficiency, these devices may be used at the same time.

The textual announcement should contain in particular:

- the exact location and time of the incident;

- the expected impacts of the incident;

- the extent of the impact;

- the expected duration of the impact;

- the proper rules of conduct;

- the further information possibilities.

The message should cover:

- the vulnerable area;

- the nature of the hazard;

- the tasks of protection against the hazard;

- the expected time of the occurrence of the hazard;

- the specificity of the message;

- the consistency of the message;

- its accuracy.

A message is authentic if:

- the approach is based on statistics;

- the source is reliable.

Personal requirements of emergency information:

- use of more personal and interactive methods of public information;

- the briefers should acquire appropriate behavioral psychological and sociological knowledge;

- it is necessary to assess and be aware of the behavioral psychological, socio-psycho- logical and cultural psychological characteristics of the local inhabitants;

- those organizing and implementing public information should acquire the appropriate knowledge and empathic behavior in order to raise the efficient public awareness of the vulnerable population; 
- the operator should be an experienced, suggestive, confident, easy-to-understand and a quiet-spoken person;

- the educational method of the communicators: training, advanced training.

In an emergency, those implementing emergency information cooperate (with law en- forcement bodies, nongovernmental charitable organizations, etc.) for the sake of authentic, accurate and fast information, during which they harmonize the main areas of the informa- tion, the method of coordinated flow of information, the range of the population directly and indirectly affected and the possible international impacts.

The essence of emergency information:

- by ensuring immediate information, we have to avoid the spread of rumors and false information;

- the positive feelings (hope, vision) in people should be strengthened.

\subsubsection{New possibilities in the field of emergency information}

After the occurrence of an incident or a disaster, the number of public distress calls increas- es. In many cases the distress call systems get overloaded or overflow. Within social media, Facebook for instance, can be used for requesting or offering help or providing information in an emergency.

Abroad, during Hurricane Sandy, the Federal Emergency Management Agency (FEMA), EMS Paramedic and the U.S. Army Corps of Engineers, etc. used social media for the early warning of the population and for emergency information to replace the overloaded public emergency call number 911 (it was activated at a voluntary nongovernmental initiative). In Hungary, during the snow situation in March 2013 and the flood in June of the same year, the use of social media became customary in the field of emergency information. In the opin- ion of the authors, social media not only may but should be used to raise public awareness and for, (emergency) information purposes, because through social media, many people may be accessed. The official Facebook page of the National Directorate General for Disaster Management (hereinafter NDGDM) was visited by several hundreds of thousands for the information on the June flood. In this emergency, Facebook had a significant role, but what is more important is that people were looking for information from the authorities, therefore, the emergency content received an even greater attention.

Generally speaking, through fast and authentic information the population's "faith in gov- ernmental competence" grows, because, with the help of new possibilities introduced in the field of emergency communication and information, paragraph (2) of article G) of the Funda- mental Law would prevail: "Hungary protects its citizens".

In 2013, the public formation toolbox of professional disaster management was extended. The organization uses, besides traditional methods, social media (Facebook) and an appli- cation developed for mobile devices (VÉSZ). Utilizing the advantages lying in mass com- munication, on 9 June 2013, ÁRVÍZ (FLOOD) FM started its operation for the period of emergency declared due to the flood. The novelty of the radio station was provided by its non-stop possibility to provide information that the population could continuously have ac- cess to timely information on the flood situation. The provisional channel of public media, Hungary's first flood protection radio station, due to its national reception possibility, was available to anyone. A great achievement of the radio station was that Hungary's prime min- 
ister, the minister responsible for the flood management, the defense minister and the heads of the organizations participating in the response efforts were interviewed several times, which had a psychological impact on the population in such an extraordinary situation. Radio Árvíz FM shared its up-to-date information on social media pages as well, published mainly on the Facebook portal.

In the field of public emergency information, another great achievement was the use of an emergency information application developed for smart phones and tablets, with free ac- cess nationwide, which was introduced by NDGDM on 25 November 2013. The application mainly provides meteorological and traffic news to its users, including certain interventions by the fire brigades. [13] The information was highlighted with three different colors: blue for informative, yellow for warning and red for alerts, to which individual sounds could be set. Textual information is also supported by map a display.

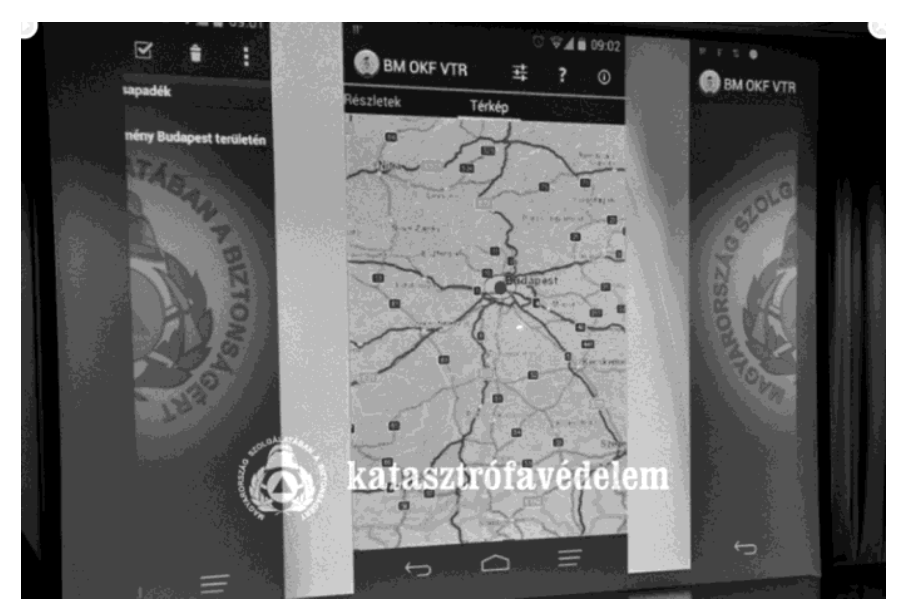

Picture 1. Map support of the NDGDM Emergency Notification Service (Veszélyhelyzeti Értesitési Szolgáltatás - VÉSZ)

(Photo by NDGDM [14])

VÉSZ is an option meeting the IT and information requirements of our era, through which emergency information and notification of citizens can be ensured for a wide range of the population, thus the protection of life and property safety is supported by another means.

\subsubsection{The significance of an interactive map in emergency information}

With reference to the snow situation of March 2013, citizens shared a map on Facebook (a type of social media), named social networking map by them. From the 46 shares, it can be seen that the population needs these maps. The 46 shares mean that a minimum of 46 persons saw and (hopefully) used the map. With the miniature spots on the map, different locations (keep-warm shelters, reception sites, etc.) are displayed: 


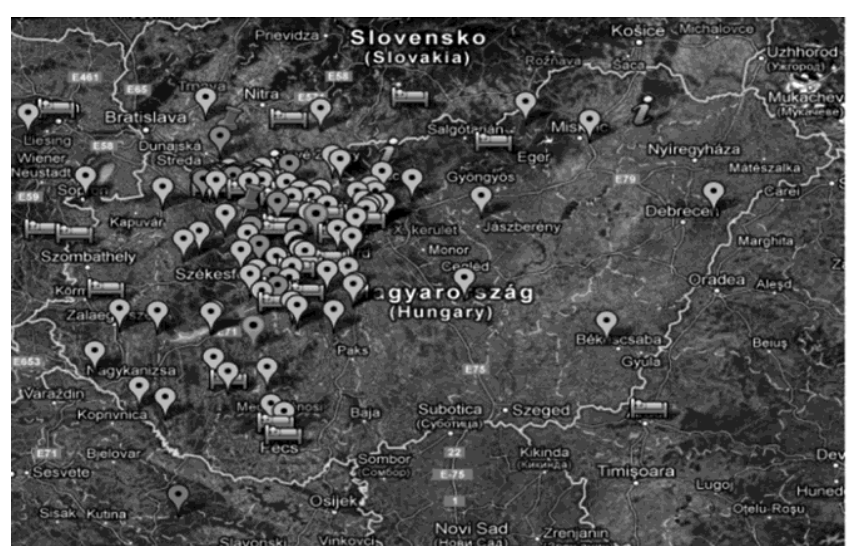

Picture 2. Interactive map during the snow situation of March [2]

A great advantage of interactive maps is that the number and deployment sites of volunteers can also be displayed; thus the heads of the professional disaster management organs and the experts of the protection committees can visually display the situation to help prepare decisions.

The data needed for the maps can be collected, on the one hand, through their own net- works (social media, websites, telephony communications, operations duty offices, etc.), on the other hand, through cooperation agreements and by the population.

\section{Introduction and Significance of the Emergency Information and Communication System when Providing Emergency Information}

The above examples are generally used separately when providing information and training. VÉSZ and the interactive map ensures one-way communication, however, social media can provide two-way communication. The main goal is to strengthen two-way communication when providing emergency information and raising public awareness. Social media, the te- lephony network, the application, the homepage and the emailing system should be "amal- gamated" into an IT system.

In the authors' opinion, conventional methods should be combined with the new possibil- ities of the $21^{\text {st }}$ century. A complex information system should be created, which is dedicated to ensure the survivability of the population through training and briefings before, during and after the occurrence of a disaster. This would be the Emergency Information and Notification System (hereinafter VITÁR), which would help the operation of the professional disaster management system, cooperating with other non-governmental voluntary organizations es- tablished for the protection of the population. The basis for its establishment are the disasters and incidents of recent years, which are emerging in a more and more complex way. With the development of civilization, there is an increasing number of threats in our environment, and global climate change results in more and more localized meteorological anomalies, therefore, in order to facilitate the protection of the population and the work of disaster man- agement, it is necessary to establish a system that is based on two-way and controllable communication, promoting the preparation of the population and raising public awareness. 
VITÁR, amongst others, is dedicated to providing information, guidance, advice and knowledge to people and communities in trouble in due time and through appropriate means, thus increasing the individual's and groups' survivability. VITÁR intends to achieve and en- sure it through a national green number telephone connection, a homepage accessible from any part of the world, its own Facebook site, a free downloadable mobile application and a restricted internal information system (in close cooperation with disaster management).

The following main issues may arise in case a disaster occurs, whose management and solution VITÁR wishes to achieve:

- Managing, analyzing and evaluating increased numbers of distress calls, if necessary, transmitting them to the competent entities. The transmission of possible emergency calls arriving by phone to the 112 emergency call system. Handling emergency calls in their own right, localization of emergencies;

- The inhabitants (people in need), in case of necessity, are not continuously informed of the situation developing, and they receive false information or useless advice from several places. This must be managed. By making the information from a reliable source available to the population, negative information should be rectified and the harmful impacts of disinformation can be decreased. Emergency information in real time. With the exception of the information in connection with telephony, the other information providing methods share the interactive maps of civilian use;

- For local incidents, the population does not receive reassuring information, or no infor- mation on the proper rules of conduct;

- Communication from and to the population in an interactive way;

- The voluntary rescue organizations may be (are) alerted, however, helpers without a rescue organization (the wide range of the population itself) and donors will only learn later that their assistance is needed (it is possible to overcome with an information module integratable into the system, through which the volunteers can be reached, information may be provided to them). Facilitating the recruitment of and providing dynamic information to voluntary rescue organizations. Registering and controlling the voluntary, map display of their location.

The authors assume that the information published on the website, Facebook and the ap- plication will be sufficient to help a person to find safe haven. If the individual does not get into a life threatening situation and the emergency information published on Facebook and the website or the operator's assistance on VITÁR telephone are sufficient, he does not have to use the 112 unified emergency call system (hereinafter Emergency Call System), then no further load from the population is put on the telephone network of Emergency Call System in the period of mass emergency calls. The goal of VITÁR is to ensure the possibility of a public distress call for the population (in cases when there is no imminent danger to life) on its own system through suitable devices (operator controlled telephony system, Facebook, mobile application). It does not have the goal to raise the awareness of the population of launching emergency calls through VITÁR in case of danger to life (to do so they have the more suitable Emergency Call System). The management of situations without the danger to life, involving public information, is the main goal of VITÁR.

Emergency information can also be accessed through the mobile application of VITÁR, thus facilitating the mobilization of the inhabitants to leave their residences more easily (they do not even have to take their laptops with themselves). During an emergency or at the im- 
minent threat thereof, VITÁR can send an emergency warning. There is an emergency call shortcut function on the mobile application, which is a GPS-based positioning system with smart phones; with older versions, cellular positioning can send or relay lifesaving emergen- cy information.

Another objective of the non-stop functioning VITÁR is to track the citizens' initiatives in normal times and in classified periods. The aim is to monitor public organizations, interpret and analyze the information posted and shared on the websites, to eliminate disinformation; analyze public reactions, avoid or manage eventual panicking. Where there is a panic-type of mood, VITÁR compiles a so-called "reassuring and calming package" and broadcasts through its application and social media.

Based on public photos, videos and announcements the processes in a given area can be accumulated. For instance, during a flood, through public photos, it is possible to create an overall picture of the status of an area. VITÁR continuously monitors them on the Internet, collects and assesses them, and based on reports, dispatches them to the competent Coun- ty Disaster Management Directorates (hereinafter Directorate), facilitating the Directorate's decisions on the protection. If the Directorates need it, invitations encouraging voluntary assistance may be sent to VITÁR.

Contacts with the owners and operators (admins) of major portals should be established. If admins ask for information from VITÁR, disinformation can be reduced, since the system ONLY publishes data based on certain authoritative information with the approval of the na- tional civil protection inspector general. Another reason why contacts should be extended to non-governmental initiatives is that they recruit and mobilize a great number of volunteers on their websites, so one should count with this potential.

As a summary, VITÁR is a controlled two-way communications system, composed on the basis of specific protocols, through which society can have access to emergency informa- tion. VITÁR provides assistance to professional organs in the management of an emergency (recruiting and coordinating volunteers, raising public awareness, emergency information, receiving and relaying distress calls, receiving donations and offers, continuous collection, analysis and assessment of data on public reactions, feelings, etc.). VITÁR intends to avoid mass hysteria by providing reliable local information. At the same time, provides informa- tion on the proper rules of conduct, in a given situation, ensures further information on the management of an emergency.

The Emergency Information and Notification System is NOT meant to organize on its own; the criterion of its functioning is the knowledge of the protection mechanism of profes- sional organs and continuous communication and the authorization of the national inspector general for civil protection. The objective is to help the work of the professional disaster management.

\section{Summary of the Study}

The Cold War approach has gradually developed into actions and response activities against the challenges caused by natural disasters. The range of risks and hazards threatening safety and security has grown and become more complex. Incidents in recent years, originating in nature or humans activity, all show that society is vulnerable anywhere and at any time at a certain level. By raising public awareness and providing emergency information, this vulner- 
ability and exposure may be reduced. To this end, continuous research and analyses should be carried out on what means are suitable for communication and are used or kept by the major- ity of the members of the society. With the development of infocommunication technologies, the possibilities of providing information to the population have increased. Gathering infor- mation from the communities has now become simpler and faster. As the snow situation in March 2013 and the flood in June of the same year have shown, the population requires that the professional organs use these new infocommunications technologies. Social media can be used in the phases of prevention, response and recovery as an option to convey information. Amongst the tools of social media Facebook may be the platform, on which a wide range of the population can be reached (of course, besides conventional methods). Facebook can now be accessed on mobile phones. This access makes it possible for people to have access to the necessary emergency information, roadblocks, major data on vulnerable areas, etc. All this contributes to the fact that an inhabitant can receive real-time information. It is important to monitor and analyze the amalgamation of non-governmental initiatives on social media, and to plan the necessary counteractions to eliminate possible disinformation.

When providing emergency information, visualization is more and more a requirement, therefore, the support with interactive maps comes to the fore.

The main goal of emergency information is to ensure the safety of life and property to the greatest extent possible.

\section{Conclusions}

In order to protect Hungary's population and property, and to be able to respond to current challenges in the most efficient way, professional disaster management has been transformed structurally. Within the three main fields, civil protection is one of the most important scopes of tasks to protect the population. The snow situation in March 2013 and the flooding in June of the same year have increased the significance of the role of civil protection by today (mainly emergency information, preparedness, coordinating and controlling volunteers).

Transfer of information through the Internet, compared to the previous conventional methods (television, radio, printed press, etc.), has incredibly changed the notification meth- ods, to which a new language culture should be implemented.

The population (mainly those in trouble and need), following or during an incident or disaster, are not continuously informed of a situation, or they receive false information or useless advice from numerous sources. To provide a remedy, the Emergency Information and Notification System was introduced, which provides year-long public awareness materials for the population (prevention), in an emergency, it sends briefings from verified sources to citizens.

The new kind of public emergency communication possibilities may also be used for preventive purposes. With the help of well-marketed and managed social media, mobile applications, websites, publications, etc. a wide range of the population can be addressed concerning the protection against disasters, and can attract it as a civil protection potential to the disaster management system, in the service of Hungary for safety and security. 


\section{Recommendations of the Study}

The most significant factor amongst societal impacts is the change of communication affect- ing a wide range of the population. Accordingly, the technical advantages of the era should be utilized in the protection against disasters. To illustrate disasters and incidents in a clearer and understandable way geographic information system (GIS) support is needed, through which a higher level of professional public awareness information can be created.

The younger generations use digital devices in a skilled way. These applications have be- come the integral part of their lives to such an extent that the majority shares all phenomena immediately. The possibilities of social media (not only Facebook) supporting the protection against disasters should be studied in a more profound way; the authors recommend creating a uniform framework, by establishing a strategy, on its joint use (website, Facebook, appli- cations, publications, etc.).

It is important, with regard to the technological and social changes in the $21^{\text {st }}$ century that besides the means and devices, (conventional) methods currently used in public emergency information, new opportunities should be put in place and adapted.

It should be considered that when preparing people living in farms and providing them emergency information, a protocol should be compiled, increasing their protection capacities.

\section{References}

[1] Magyarország Alaptörvénye. Magyar Közlöny, 43 (2011. április 25.) www.keh.hu/index_gy.php?submenu=magyarorszag_alaptorvenye \&cat $=29 \&$ mcat $=3 \&$ details $=1 \& \mathrm{id}=1515 \& \mathrm{pnr}=2$ (downloaded: 0302 2014)

[2] Hóhelyzet 2013. március www.facebook.com/pages/H\%C3\%B3helyzet-2013-m\%C3\%A1rcius/229924473820111 (downloaded: 0302 2014)

[3] Árviz 2013 Összefogás. www.facebook.com/Arviz2013Osszefogas (downloaded: 0302 2014)

[4] BM OKF (2014): A lánctalpastól az önmelegítö raguig. Budapest : BM Országos Katasztrófavédelmi Főigazgatóság. www.katasztrofavedelem.hu/index2. php?pageid=szervezet_hirek\&hirid=2504 (downloaded: 03 02 2014)

[5] ENDRÖDI I. (2007): A katasztrófa-elháritásra felkészitö ismeretek. Budapest: BM Rendörtiszti Föiskola. www.google.hu/url?sa=t\&rct=j\&q=\&esrc=s\&source=web\&cd= $1 \&$ ved=0CC8QFjAA\&url=http\%3A\%2F\%2Fwww.mpvsz.hu\%2Fkpanyag\%2Fdownload. php\%3Fid\%3D5\&ei=ulLzUprAGueJywO4voDIAw\&usg=AFQjCNGsOhbjmGw833lor3h3 Itkz4a6x0g\&sig2=YPaQwf8byqZPSGecH4J-LA\&bvm=bv.60799247,d.bGQ (downloaded: 0302 2014)

[6] HORNYACSEK J.: A lakosság védelmének újszerü értelmezése és alkalmazási lehetőségei a New Orleans-i Katrina hurrikán eseményeinek tapasztalata alapján. Müszaki Katonai Közlöny, XXI 1-4 (2011), 1-24. ISSN 2063-4986. www.hhk.uni-nke.hu/downloads/ kiadvanyok/mkk.uninke.hu/pdfanyagok2011/21\%20katrina\%20cikk\%20HJ\%20leadott.pdf (downloaded: 0302 2014) 
TEKNŐS László, ENDRŐDI István: New possibilities of emergency communication and information...

[7] TEKNÖS L.: A Sandy hurrikán Egyesült Államokat sújtó hatásainak elemzése II. Hadmérnök, VIII 2 (2013), 283-305. ISSN 1788-1919 www.hadmernok.hu/132_24_teknosl.pdf (downloaded: 0302 2014)

[8] KÁTAI-URBÁN L., VASS Gy. (2009): Katasztrófavédelem: Útmutató a biztonsági dokumentáció elkészítéséhez. In. Ferencz M., Kátai-Urbán L., Körtvélyessy Gy., Nemeskey K., Sárosi Gy., Sulcz Á., Szentes E., Vass Gy., Sárosi Gy. (Eds.), Veszélyes áruk szállitása és tárolása. Budapest: Verlag Dashöfer Szakkiadó, 1-54. ISBN:963 8591528

[9] KÁTAI-URBÁN L. ( 2005): Information to the public. In. Bíróné Ö. J., Bojti I., Cimer Zs., Damjanovich I., Hoffmann I., Mógor J., Szakál B., Vass Gy., Kátai-Urbán L. (Eds.), Guidance on the implementation of regional and local tasks for the prevention of major accidents involving dangerous substances. Budapest: Akaprint Kft. 40-53. ISBN 963219

1129

[10] 2011. évi CXXVIII. törvény a katasztrófavédelemről és a hozzá kapcsolódó egyes törvények módosításáról. www.net.jogtar.hu/jr/gen/hjegy_doc.cgi?docid=A1100128.TV (downloaded: 0302 2014)

[11] 234/2011. (XI. 10.) Korm. rendelet a katasztrófavédelemröl és a hozzá kapcsolódó egyes törvények módosításáról szóló 2011. évi CXXVIII. törvény végrehajtásáról.

www.jogszabalykereso.mhk.hu/cgi_bin/njt_doc.cgi?docid=141325.572678 (downloaded: 03 02 2014)

[12] 2010. évi CLXXXV. törvény a médiaszolgáltatásokról és a tömegkommunikációról. www.net.jogtar.hu/jr/gen/hjegy_doc.cgi?docid=A1000185.TV (downloaded: 0302 2014)

[13] BM OKF (2013): Androidon már érkeznek a jelzések. Budapest: BM Országos Katasztrófavédelmi Főigazgatóság. www.katasztrofavedelem.hu/index2. php?pageid=szervezet_hirek\&hirid=2346 (downloaded : 0203 2014)

[14] BM OKF (2013): Androidon már érkeznek a jelzések. Budapest: BM Országos Katasztrófavédelmi Főigazgatóság. www.katasztrofavedelem.hu/index2.php?pageid=press_keptar_mutat\&galeria_id=1646 (downloaded: 0302 2014) 